TAO, Vol. 16, No. 4, 909-917, October 2005

\title{
Tritium Concentrations and Radiocarbon Ages of Gushing Groundwater from Hsuehshan Tunnel, Northern Taiwan
}

\author{
Tsung-Kwei Liu ${ }^{1}{ }^{1}{ }^{*}$, Cheng-Hong Chen ${ }^{1}$, Tsanyao Frank Yang $^{1}$, and Ming Lee ${ }^{2}$
}

(Manuscript received 1 September 2004, in final form 20 July 2005)

\begin{abstract}
Several serious groundwater outbursts occurred during excavation of the Hsuehshan Tunnel in northern Taiwan. In order to better understand the hydrological characteristics of the rock formations overlying the tunnel, tritium $\left({ }^{3} \mathrm{H}\right)$ concentrations and radiocarbon $\left({ }^{14} \mathrm{C}\right)$ ages of groundwater samples from the tunnel were measured. Samples from the gently dipping and less fractured sandstone/shale beds of the Makang Formation to the west have ${ }^{3} \mathrm{H}$ content of less than $0.6 \mathrm{TU}$ and conventional ${ }^{14} \mathrm{C}$ ages of older than $8400 \mathrm{yrBP}$, suggesting pre-bomb recharge and relatively low flow rates $\left(\leq 8 \mathrm{~m} \mathrm{yr}^{-1}\right)$. In contrast, samples from the highly fractured and steeply dipping Szeleng meta-sandstone to the east have ${ }^{3} \mathrm{H}$ contents of 1.2 2.5 TU and conventional ${ }^{14} \mathrm{C}$ ages of younger than $7400 \mathrm{yrBP}$, implying origin of post-1999 recharge and higher flow rates of $130 \sim 500 \mathrm{~m} \mathrm{yr}^{-1}$. Tritium and carbon isotopes concentrations reflect local hydrogeological characteristics of the rock formations along the Hsuehshan Tunnel and were helpful in assessing excavation methods.
\end{abstract}

(Key words: Tritium, Radiocarbon, Groundwater, Tunnel, Taiwan)

\section{INTRODUCTION}

The NE-SW trending Hsuehshan Range forms a land transportation barrier between the Taipei metropolitan and Ilan County. The $12.9 \mathrm{~km}$ long Hsuehshan Tunnel, which consists of two $11.8 \mathrm{~m}$ wide main-tube tunnels and a $4.8 \mathrm{~m}$ wide pilot tunnel, is a key component in the $31 \mathrm{~km}$ long Taipei-Ilan expressway (Fig. 1). During the excavation of the tunnels, several groundwater outburst events occurred, resulting in serious delays in the tunnel construction

\footnotetext{
${ }^{1}$ Department of Geosciences, National Taiwan University, Taipei, Taiwan, ROC

2 Central Geological Survey, MOEA, Taipei County, Taiwan, ROC

* Corresponding author address: Dr. Tsung-Kwei Liu, Department of Geosciences, National Taiwan University, Taipei, Taiwan, ROC; E-mail:iutk@ntu.edu.tw
} 


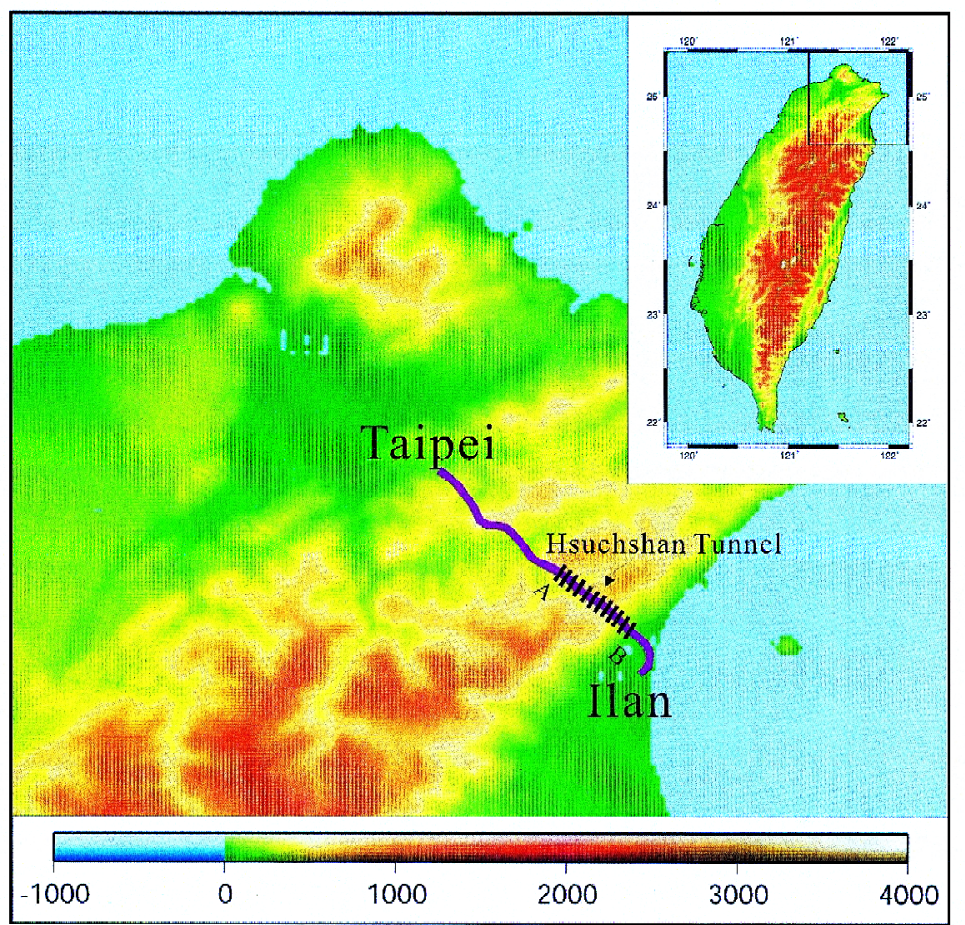

Fig. 1. Location of the Taipei-Ilan Expressway (thick purple line) and the Hsuehshan Tunnel.

schedule. In order to estimate hydrological characteristics such as recharge and flow rates, amount of groundwater storage, and continuity of fractures, tritium concentrations and radiocarbon ages of groundwater samples collected from seven water-outburst sites (Fig. 2) within the tunnels were measured. Because the tunnel is overlain by rugged hills with limited catchment area above the tunnel level, it is reasonable to infer that the gushing groundwater was recharged from local surface/rain water.

Geochemical investigations can help to better understand the origin and/or source of the natural hazards (e.g., Andal et al. 2005; Etiope et al. 2005a, b; Knittel et al. 2005; Lee et al. 2005; Pecoraino and Giammanco 2005). Especially, tritium concentrations can well constrain the source and age of groundwater in one area. "Bomb-tritium" produced by above-ground thermonuclear tests beginning in 1953 has proven to be an excellent tracer and/or time marker in hydrological systems (e.g., Brown 1961; Allison and Hughes 1975; Egboka et al. 1983; Robertson and Cherry 1989; Daniels et al. 1991; Liu 1995). Before 1953, natural ${ }^{3} \mathrm{H}$ concentrations in precipitation at the lower latitudes were estimated at 3.4 to 6.6 tritium units (TU) (Kaufman and Libby 1954). During the mid-1960s, ${ }^{3} \mathrm{H}$ activity in precipitation rose rapidly to hundreds or thousands of TU in the northern hemisphere (<www.iaea.or.at:80/programs/ri/ gnip/gnipmain.htm >). Thus ${ }^{3} \mathrm{H}$ content of pre-bomb (i.e., before 1952) precipitations are now much lower than those of post-1952 precipitations. 
Liu et al.

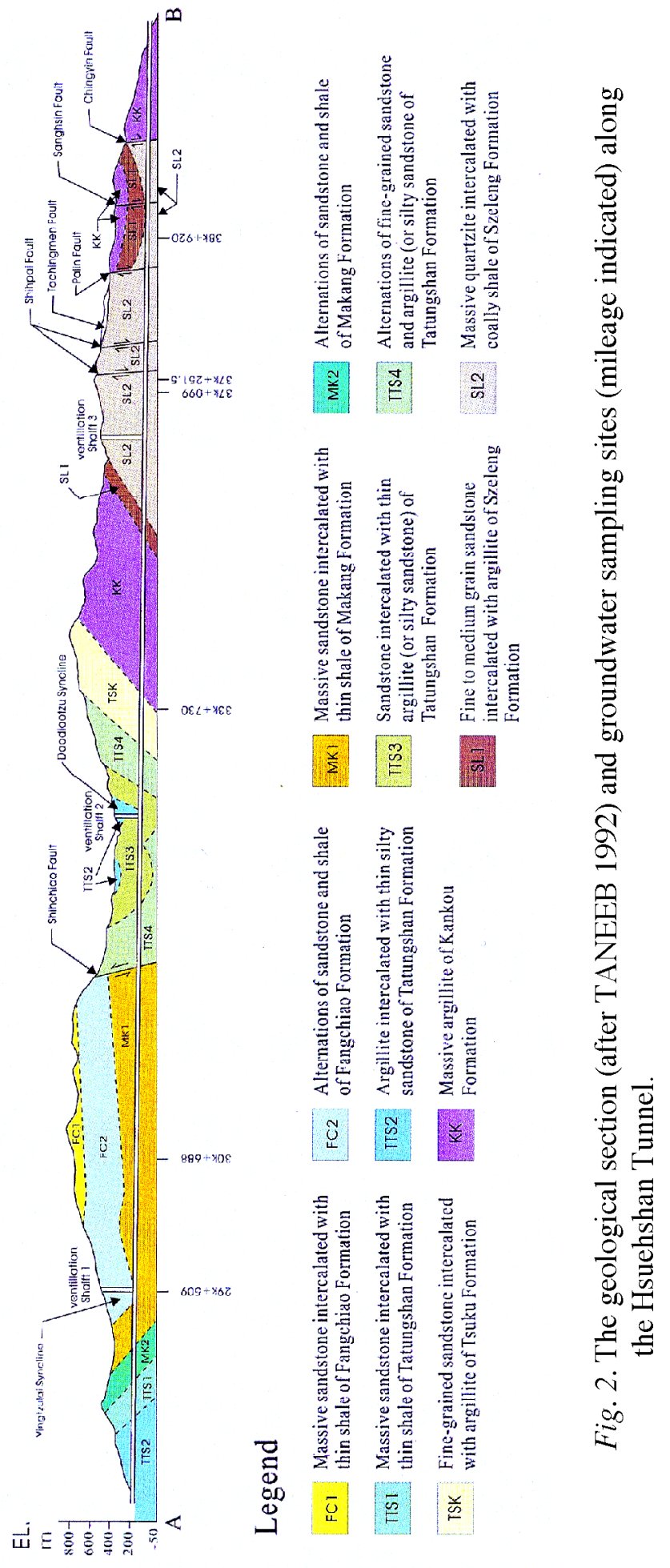




\section{GEOLOGICAL CONDITIONS}

Six rock formations of Paleogene epoch were encountered along the Hsuehshan Tunnel (Fig. 2). Metamorphic grade generally increases eastward. In the western half of the tunnel, rocks are mainly unmetamorphosed massive sandstone and sandstone-shale alternations of the Fangchiao and Makang Formations. Well-developed joints and shear zones are often filled with clay and/or angular rock fragments. In contrast, the eastern half is composed dominantly of argillite from the Kangkou and Tatungshan Formations and the Szeleng meta-sandstone (or quartzite). Both formations are highly fractured, but intact fresh blocks of the Szeleng metasandstone have a high uniaxial compressive strength of $2,000 \mathrm{~kg} \mathrm{~cm}^{-2}$ or more. It is rigid and strong, but highly fractured or faulted Szeleng meta-sandstone that caused serious groundwater outbursts and hindered the excavation of the tunnel.

The tunnel construction schedule has been delayed for more than five years due to the geological conditions. The tunnel overburden is greater than $700 \mathrm{~m}$ at its maximum depth and engineers anticipated that the tunnel would penetrate many major faults. Original plans were for tunnel-boring machines (TBMs) to be used to excavate the entire lengths of the pilot and main tunnels; however, the degree of contrast between the stronger Szeleng quartzite and the soft clay fillings made use of the TBM unsuitable in some sections of the tunnels.

\section{SAMPLING AND RADIOMETRIC ANALYSIS METHODS}

Water samples were collected during the very early stage of each major water-outburst event during tunnel excavation. Repeated samplings, separated by nearly four months, were made at the site of $30 \mathrm{~K}+688$ in order to see whether there is significant variation with time.

The sampling and analytical methods used in this study are similar to those of Hackley et al. (1992) and Liu (1995). Two types of water samples were collected from each gushing site: a 45-liter sample for ${ }^{14} \mathrm{C}$ dating and a 1-liter sample for ${ }^{3} \mathrm{H}\left(\mathrm{t}^{1 / 2}=12.43 \mathrm{yr}\right.$; Unterweger et al. 1980; Lucas and Unterweger 2000) measurement. Dissolved inorganic carbon (DIC) was precipitated in the field. Atmospheric $\mathrm{CO}_{2}$ was prevented from entering the 50-liter carbon during water sampling and precipitation. Two liters of $0.5 \mathrm{M} \mathrm{BaCl}_{2}$ and 2 liters of $0.5 \mathrm{~N} \mathrm{NaOH}$ solutions were added to the water sample through a spigot and mixed thoroughly. After settling, the precipitate was siphoned through the spigot into a 4-liter vacuum flask and rinsed repeatedly by $\mathrm{CO}_{2}$-free deionized water. The slurry $\left(\mathrm{BaCO}_{3}\right)$ was converted first to $\mathrm{CO}_{2}$ and finally to benzene in a vacuum system. ${ }^{14} \mathrm{C}$ activity was measured using liquid scintillation counting. All $\delta^{13} \mathrm{C}_{\text {DIC }}$ values were determined for the $\mathrm{CO}_{2}$ gas produced at the initial stage of benzene synthesis. Tritium concentrations were measured by liquid scintillation counting method after isotopic enrichment through electrolysis of $200 \mathrm{ml}$ of water samples.

\section{RESULTS AND DISCUSSION}

Seven water samples were collected from 6 gushing sites along the Hsuehshan Tunnel (Fig. 1; Table 1). Four rainfall samples collected in 1995, 1996 and 2004 from Taiwan show 
recent ${ }^{3} \mathrm{H}$ contents of between 1.5 and 3.5 TU (Table 2), which can represent the pre-bomb ${ }^{3} \mathrm{H}$ contents of this region. As the last pre-bomb precipitation occurred in 1951, the natural activity of pre-bomb precipitation in the Taiwan area had decayed for $\sim 4$ half-life time spans to $\leq 0.5 \mathrm{TU}$ in 1999 and thereafter. Thus, the practical rule in Taiwan for identifying old groundwater ( $>50 \mathrm{yr}$ old) is $<0.5 \mathrm{TU}$. In other words, the groundwater with ${ }^{3} \mathrm{H}$ activity $>1 \mathrm{TU}$ was certainly recharged from the surface after A.D. 1952.

Table 1. Results of tritium and carbon isotopes analyses of groundwater from the Hsuehshan Tunnel, northern Taiwan.

\begin{tabular}{|c|c|c|c|c|c|c|c|}
\hline $\begin{array}{l}\text { Sample } \\
\text { no. }\end{array}$ & Location & $\begin{array}{l}\text { Sampling } \\
\text { date }\end{array}$ & $\begin{array}{l}{ }^{3} \mathrm{H} \pm 1 \sigma \\
\text { (TU) }\end{array}$ & $\begin{array}{c}{ }^{14} \mathrm{C}_{\mathrm{DIC}} \text { Age } \\
(\mathrm{yr} \mathrm{BP})\end{array}$ & $\begin{array}{c}\delta^{13} \mathrm{C}_{\mathrm{DIC}} \\
(\% 0)\end{array}$ & $\begin{array}{l}{ }^{13} \delta \text { corr. }{ }^{14} \mathrm{C}_{\mathrm{DIC}} \\
\text { Age }^{*}(\mathrm{yr} \mathrm{BP})\end{array}$ & $\begin{array}{c}\text { Discharge rate } \\
\text { (liters/sec) }\end{array}$ \\
\hline 1. & $29 k+509$ & $12 / 07 / 1999$ & $0.6 \pm 0.2$ & $8450 \pm 50$ & -13.7 & 3610 & (not measured) \\
\hline 2. & $30 k+688$ & $05 / 07 / 2001$ & $<0.2$ & $19100 \pm 200$ & -10.8 & 12350 & $2 \sim 3$ \\
\hline 3. & (ibid) & $14 / 03 / 2001$ & $<0.2$ & & & & \\
\hline 4. & $33 k+730$ & $25 / 09 / 2002$ & $1.6 \pm 0.2$ & $5050 \pm 150$ & -14.5 & 670 & $\sim 50$ \\
\hline 5. & $37 \mathrm{k}+251.5$ & $04 / 03 / 2001$ & $2.5 \pm 0.2$ & $5530 \pm 90$ & -13.2 & 400 & $10 \sim 15$ \\
\hline 6. & $37 k+099$ & $25 / 04 / 2001$ & $1.5 \pm 0.2$ & $7340 \pm 110$ & -13.3 & 2270 & $40 \sim 60$ \\
\hline 7. & $38 k+920$ & $06 / 07 / 1999$ & $1.2 \pm 0.2$ & $5500 \pm 100$ & -14.0 & 840 & (not measured) \\
\hline
\end{tabular}

$* \delta{ }^{13} \mathrm{C}_{\text {corrected }}{ }^{14} \mathrm{C}_{\mathrm{DIC}}$ age $={ }^{14} \mathrm{C}_{\mathrm{DIC}}$ age $+18510 \log \left(\delta^{13} \mathrm{C}(\%) /-25\right)$.

Table 2. ${ }^{3} \mathrm{H}$ contents of recent rainfalls in Taiwan.

\begin{tabular}{cccc}
\hline Location & Date & ${ }^{3} \mathrm{H}(\mathrm{TU})$ & Analyst \\
\hline Taipei (N. Taiwan) & $17 / 05 / 1995$ & $3.39 \pm 0.12$ & ${ }^{3} \mathrm{H}$ Laboralory, Univ. Miami \\
Pintung (S. Taiwan) & $10 / 07 / 1995$ & $1.53 \pm 0.09$ & ibid \\
Taipei (N. Taiwan) & $28 / 09 / 1996$ & $1.63 \pm 0.09$ & ibid \\
Taipei (N. Taiwan) & $08 / 02 / 2004$ & $1.5 \pm 0.2$ & Radiocarbon Laboratory, National Taiwan Univ. \\
\hline
\end{tabular}


Repeated sampling and measurements showed that the ${ }^{3} \mathrm{H}$ concentration of sample no. 2 was below the lower detection limit $(<0.2 \mathrm{TU})$, demonstrating that the groundwater was older than 50 years. The ${ }^{14} \mathrm{C}$ age of the sample is about $19000 \mathrm{yrBP}$; the ${ }^{13} \mathrm{C}$-corrected age of which is still very old (i.e., about $12000 \mathrm{yrBP}$ ) as compared with the other samples. It is worth noting that this sample was collected from the relatively gentle dipping and less fractured sandstone/ shale of the Makang Formation. In addition, the discharge rate at this site was only 2 - 3 liter/sec, which was small as compared with samples no. 4 7 collected from the eastern part of the tunnel.

In contrast to the low tritium concentrations of the western samples, all the four samples from the eastern part of the tunnel were obviously greater than $0.5 \mathrm{TU}$, implying that these waters infiltrated from the ground surface after AD 1953. During recent years, namely after 1980 's, the atmospheric reservoir has been practically exhausted of the ${ }^{3} \mathrm{H}$ introduced by the nuclear tests so that atmospheric ${ }^{3} \mathrm{H}$ levels have almost returned to the pre-1952 levels (Rath 1988; Daniels et al. 1991). Because the post-1952 tritium concentrations of groundwater measured in 1991 in the Taiwan region were almost all greater than 4 TU (Liu 1995), they should still be greater than $2.6 \mathrm{TU}$ in 1999 due to radioactive decay. Thus the eastern groundwater samples, which had tritium concentrations between 1.2 and $2.5 \mathrm{TU}$ measured in 1999 or later, were considered to be younger than AD 1999. The recharge area in the eastern part is at an altitude of $700 \pm 100 \mathrm{~m}$, and the tunnel is at an altitude of about $200 \mathrm{~m}$. Thus the groundwater there descended about $500 \mathrm{~m}$, giving a mean downward flow velocities between $500 /(2000-1999)=500 \mathrm{~m} \mathrm{yr}^{-1}$ and $400 /(2002-1999)=130 \mathrm{~m} \mathrm{yr}^{-1}$. The high flow velocities obtained are consistent with the observed geological and hydrological characteristics of the Szeleng meta-sandstone (Fig. 3) such as well-developed high-angle joints/faults and large groundwater discharges in the eastern part of the tunnel. Accordingly, it would be inappropriate to expect a rapid decline in the amount of gushing water and to proceed with tunnel excavation under favorably drier conditions. As a result, it was decided that traditional "drill and blast" (D\&B) methods for rock excavation would be conducted for the highly fractured parts of the Szeleng meta-sandstone.

Except for the relatively older sample from $30 \mathrm{~K}+688$, which have heavier carbon isotope ratio $\left(\delta^{13} \mathrm{C}=-10.8 \%\right)$, all the other samples analyzed have a very narrow range of $\delta^{13} \mathrm{C}$ values between -13.2 and $-14.5 \%$. Apparently, the dissolved inorganic carbon in each water sample was a mixture of soil $\mathrm{CO}_{2}\left(\delta^{13} \mathrm{C}\right.$ about $-27 \%$ ) and "dead" carbon from carbonate $\left(\delta^{13} \mathrm{C} \sim 0 \%\right.$ ) (Stuiver and Polach 1977) through the reaction shown below.

$$
2 \mathrm{CO}_{2 \text { (soil) }}+\mathrm{H}_{2} \mathrm{O}+\mathrm{CaCO}_{3}==\mathrm{Ca}^{2+}+2 \mathrm{HCO}_{3}^{-}+\mathrm{CO}_{2}(\mathrm{aq})
$$

Here, the initial ${ }^{14} \mathrm{C}$ activity of dissolved inorganic carbon can be corrected by the dilution factor $(\mathrm{F})$ :

$$
\mathrm{F}=\mathrm{A}_{\Sigma C} / \mathrm{A}_{0}
$$



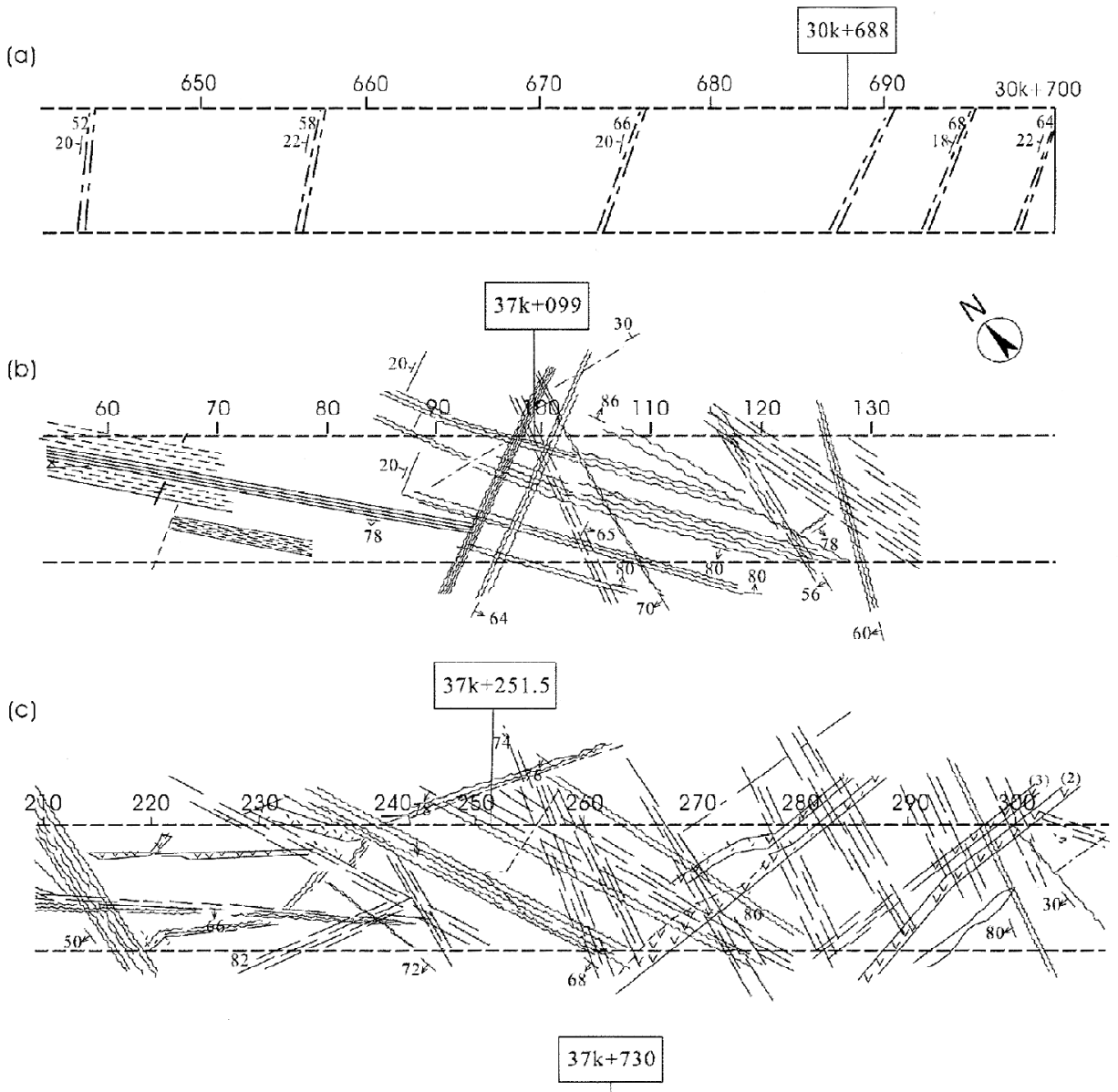

(d)

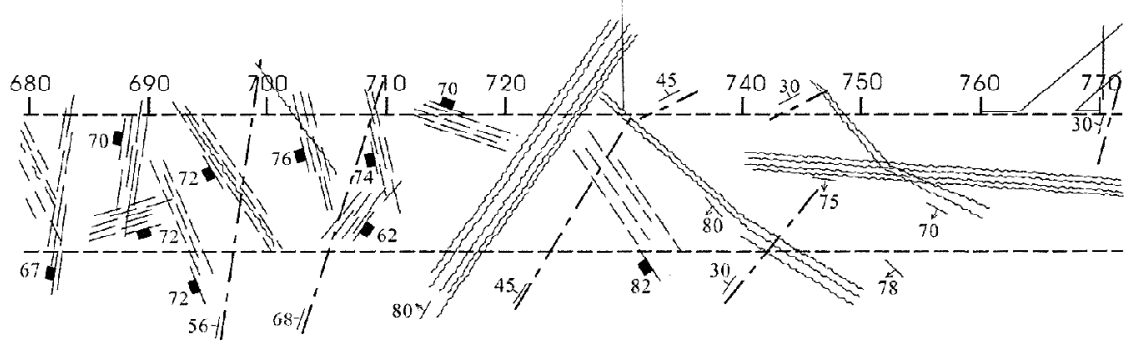

Legend

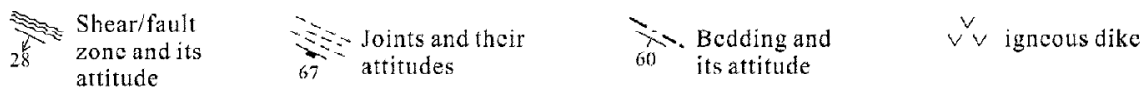

Fig. 3. Map of geological structures at the four sampling sites, showing fracture distributions at the western $(30 \mathrm{~K}+688)$ and the eastern $(37 \mathrm{~K}+)$ parts of the Hsuehshan Tunnel. 
where $\mathrm{A}_{\Sigma C}$ is the initial ${ }^{14} \mathrm{C}$ concentration of dissolved inorganic carbon; $\mathrm{A}_{0}$ is the ${ }^{14} \mathrm{C}$ activity of modern carbon standard. Using the Pearson Jr.'s (1965) isotope mixing model and mean $\delta{ }^{13} \mathrm{C}(-25 \%)$ of soil $\mathrm{CO}_{2}$, the dilution factor $\mathrm{F}=\delta{ }^{13} \mathrm{C} /-25$. Table 1 shows that the $\delta{ }^{13} \mathrm{C}$-corrected ${ }^{14} \mathrm{C}$ ages of the eastern samples (no. 4 - 7) become much younger than their original conventional ${ }^{14} \mathrm{C}$ ages, but are still significantly much older than that inferred from ${ }^{3} \mathrm{H}$ signature. It is worth mentioning that the discrepancy between ${ }^{14} \mathrm{C}$ and ${ }^{3} \mathrm{H}$ ages is also quite common for groundwater in the southwestern coastal plain of Taiwan (Liu 1995). Obviously, the groundwater under this area has slightly different inorganic carbon sources and/or carbon isotope ratios from the simple assumptions mentioned above.

\section{CONCLUSIONS}

Radioactive hydrogen and carbon isotope concentrations of the groundwater gushing out along the Hsuehshan expressway tunnel distinctly reflect local hydrogeological characteristics. The highly fractured Szeleng meta-sandstone overlying the eastern part of the tunnel had groundwater flow rates between 130 500 $\mathrm{m} \mathrm{yr}^{-1}$, which were much greater than those for the gently dipping, less fractured and unmetamorphosed sandstone/shale beds of the Makang Formation in the western section. Tritium concentrations suggest that the groundwater samples from the Szeleng meta-sandstone were recharged within three years before sampling dates. Mixing of dead carbon from carbonate dissolution made newly recharged groundwater have apparent ${ }^{14} \mathrm{C}_{\mathrm{DIC}}$ ages as old as ca. $7000 \mathrm{yrBP}$. This isotopic study was helpful in understanding hydrological characteristics and deciding excavation methods along the tunnel.

Acknowledgments The authors wish to express their gratitude to Prof. Dr. Yuch-Ning Shieh (Department of Earth and Planetary Sciences, Purdue University) and an anonymous reviewer for helpful comments. We also gratefully acknowledge Dr. Ching-Ying Lan (Institute of Earth Sciences, Academia Sinica) for her valuable suggestions. This research was supported by the National Science Council under grant NSC91-2116-M-002-031, Central Geological Survey, and Taiwan Area National Expressway Engineering Bureau, Republic of China. Thanks are due Sinotech Engineering Consulting Company and B. S. Chang for providing valuable geological and hydrological information at the sampling sites. The assistances of K. Y. Chen, D. Y. Lee and D. K. Wu in the field sampling, S. J. Kong and C. Y. Chou in ${ }^{14} \mathrm{C}$ and ${ }^{3} \mathrm{H}$ measurements, and I. L. Fan for figure drawing are appreciated.

\section{REFERENCES}

Allison, G. B., and M. W. Hughes, 1975: The use of environmental tritium to estimate recharge to a South-Australian aquifer. J. Hydrol., 26, 245-254.

Andal, E. S., G. P. Yumul, Jr., E. L. Listanco, R. A. Tamayo, Jr., C. B. Dimalanta, and T. Ishii, 2005: Characterization of the Pleistocene volcanic chain of the Bicol Arc, Philippines: implications for geohazard assessment. Terr. Atmos. Ocean. Sci., 16, 865-883. 
Brown, R. M., 1961: Hydrology of tritium in the Ottawa Valley. Geochim. Cosmochim. Acta, 21, 199-204.

Daniels, D. P., S. J. Fritz, and D. I. Leap, 1991: Estimating recharge rates through unsaturated glacial till by tritium tracing. Ground Water, 29, 26-34.

Egboka, B. C. E., J. A. Cherry, R. N. Farvolden, and E. O. Frind, 1983: Migration of contaminants in groundwater at a landfill, a case study: Tritium as an indicator of dispersion and recharge. J. Hydrol., 63, 51-80.

Etiope, G., M. Guerra, and A. Raschi, 2005a: Carbon dioxide and radon geohazards over a gasbearing fault in the Siena Graben (Central Italy).Terr. Atmos. Ocean. Sci., 16, 885-896.

Etiope, G., G. Papatheodorou, D. Christodoulou, P. Favali, and G. Ferentinos, 2005b: Gas hazard induced by methane and hydrogen sulfide seepage in the NW Peloponnesus petroliferous basin (Greece). Terr. Atmos. Ocean. Sci., 16, 897-908.

Hackley, K. C., C. L. Liu, and D. D. Coleman, 1992: ${ }^{14} \mathrm{C}$ dating of groundwater containing microbial $\mathrm{CH}_{4}$. Radiocarbon, 34, 686-695.

Kaufman, S., and W. F. Libby, 1954: The natural distribution of tritium. Phys. Rev., 93, 13371344.

Knittel, U., W. Klemm, and A. Greif, 2005: Heavy metal pollution downstream of old mining camps as a result of flood events: an example from the River System Mulde, eastern part of Germany. Terr. Atmos. Ocean. Sci., 16, 919-931.

Lee, H. F., T. F. Yang, T. F. Lan, S. R. Song, and S. Tsao, 2005: Fumarolic gas composition of the Tatun Volcano Group, northern Taiwan. Terr. Atmos. Ocean. Sci., 16, 843-864.

Liu, T. K., 1995: Estimating flow and recharge rates of groundwater in western Taiwan using radiocarbon and tritium. Radiocarbon, 37, 531-542.

Lucas, L. L., and M. P. Unterweger, 2000: Comprehensive review and critical evaluation of the half-life of tritium. J. Res. Nat. Stand. Technol., 105, 541-549.

Pearson, F. J. Jr., 1965: Use of C-13/C-12 ratios to correct radiocarbon ages of material initially diluted by limestone. Proc. of the 6th Int. Conf. on Radiocarbon and Tritium Dating, Washington D.C., 357-366.

Pecoraino, G., and S. Giammanco, 2005: Geochemical characterization and temporal changes in parietal gas emissions at Mt. Etna (Italy) during the period July 2000-July 2003. Terr. Atmos. Ocean. Sci., 16, 805-841.

Rath, K. H., 1988: Simulation der globalen ${ }^{85} \mathrm{Kr}$ und ${ }^{14} \mathrm{CO}_{2}$ Verteilung mit eines zeitabhaengigen, zweidimensionalen Modells der Atmosphare. Ph. D. Dissertation, Univ. Heidelberg.

Robertson, W. D., and J. A. Cherry, 1989: Tritium as an indicator of recharge and dispersion in a groundwater system in central Ontario. Water Resour. Res., 25, 1097-1109.

Stuiver, M., and H. Polach, 1977: reporting of ${ }^{14} \mathrm{C}$ data. Radiocarbon, 19, 355-363.

TANEEB, 1992: Introduction of Taipei-Ilan Expressway Pinglin Tunnel Project. Publ. Taiwan Area Nat. Expressway Eng. Bureau, Ministry of Transportation and Communications, Taipei, $16 \mathrm{pp}$.

Unterweger, M. P., B. M. Coursey, F. J. Schima, and W. B. Mann, 1980: Preparation and calibration of the 1978 National Bureau of Standards tritiated-water standards.Int. J. Appl. Radiat. Isotopes, 31, 611-614. 